\title{
Transcriptomic analyses reveal that the cellular Gem protein promotes HTLV-1 infected cell migration and viral transmission
}

\author{
Sébastien A Chevalier ${ }^{1 *}$, Cynthia A Pise-Masison², Antoine Gessain ${ }^{3}$, Renaud Mahieux ${ }^{1}$ \\ From 16th International Conference on Human Retroviruses: HTLV and Related Viruses \\ Montreal, Canada. 26-30 June 2013
}

In a previous study, we used gene expression microarrays and functional assays to identify cellular genes whose expression profiles were similarly affected by Tax proteins from all three HTLV subtypes (HTLV-1, HTLV-2 and HTLV-3). We found forty-eight genes up-regulated by all three Tax proteins (Chevalier et al, Plos One, 2012). Among those, Gem, which encodes a member of the Ras GTP-binding proteins superfamily, was strongly up-regulated. Herein, we first show that Gem expression is strongly up-regulated at the protein level not only in Tax-expressing cells, but also in all tested HTLV-infected cell lines and in primary uncultured $\mathrm{T}$ lymphocytes isolated from TSP/HAM patients. We then demonstrate that Tax activates transcription from the Gem promoter through the recruitment of CREB and CBP/p300 onto a cAMP Responsive Element (CRE). Gem protein has been shown to regulate reorganization of the cell cytoskeleton. Since efficient transmission of HTLV-1 from infected to uninfected $\mathrm{T}$ cells is mediated by cell-cell contacts, whose formation relies on cytoskeletal reorganization, we investigated the impact of Gem expression on cell migration and formation of cell-cell contacts. Our results show that Gem-overexpressing $\mathrm{T}$ lymphocytes display an increased spontaneous migration, while Gem-knocked down HTLV-infected cell lines show a strong reduction in their ability to migrate. We also observe that Gem enhances conjugate formation between infected and non-infected $\mathrm{T}$ lymphocytes. Altogether, our results indicate that Gem could be essential for the cell-to-cell spread of HTLV.

* Correspondence: sebastien.chevalier@ens-lyon.fr

'Oncogenèse Rétrovirale, label "Ligue Nationale Contre le Cancer", CIRI,

LabEx ECOFECT, INSERM U1111 - CNRS UMR 5308, Ecole Normale Supérieure

- Université Lyon 1, Lyon, Cedex 07, France

Full list of author information is available at the end of the article

\section{Authors' details}

'Oncogenèse Rétrovirale, label "Ligue Nationale Contre le Cancer", CIRI, LabEx ECOFECT, INSERM U1111 - CNRS UMR 5308, Ecole Normale Supérieure - Université Lyon 1, Lyon, Cedex 07, France. ${ }^{2}$ Animal Models and Retroviral Vaccine Section, Vaccine Branch, CCR, National Cancer Institute, National Institutes of Health, Bethesda, MD, USA. ${ }^{3}$ Epidémiologie et Physiopathologie des Virus Oncogènes, CNRS UMR 3569, Pasteur Institute, Paris, Cedex 15, France.

Published: 7 January 2014

doi:10.1186/1742-4690-11-S1-064

Cite this article as: Chevalier et al.: Transcriptomic analyses reveal that the cellular Gem protein promotes HTLV-1 infected cell migration and viral transmission. Retrovirology 2014 11(Suppl 1):O64.

Submit your next manuscript to BioMed Central and take full advantage of:

- Convenient online submission

- Thorough peer review

- No space constraints or color figure charges

- Immediate publication on acceptance

- Inclusion in PubMed, CAS, Scopus and Google Scholar

- Research which is freely available for redistribution

Submit your manuscript at www.biomedcentral.com/submit
() Biomed Central 